\title{
EFEKTIVITAS MODEL PEMBELAJARAN MODERASI BERAGAMA DENGAN BERBASIS MULTIMEDIA PADA PESERTA DIDIK MADRASAH IBTIDAIYAH
}

\author{
Vita Santa Kusuma Chrisantina
}

Kantor Kementerian Agama Kabupaten Kendal vitasanta17@gmail.com

DOI : http://doi.org/10.37730/edutrained.v5i2.155

Diterima: 23 November 2021 | Disetujui: 9 Desember 2021 | Dipublikasikan: 20 Desember 2021

\begin{abstract}
Abstrak
Penanaman nilai moderasi beragama perlu dilakukan internalisasi pada bidang Pendidikan. Namun implementasi pendidikan moderasi beragama masih berupa pengenalan nilai mentah sehingga perlu dilakukan pengembangan agar penerapan nilai lebih aplikatif. Tujuannya adalah mengetahui kondisi faktual implementasi pendidikan moderasi beragama sehingga dapat dikembangkan model pendidikan moderasi beragama dengan mengembangkan nilai-nilai yang lebih aplikatif. Adapun metode yang digunakan dalam penelitian ini adalah research and development yakni dengan mengembangkan nilai-nilai moderasi beragama. Penelitian dilakukan pada MIN 1 Kendal, dengan 40 responden. Analisa dilakukan dengan analisis interaktif dan N-Gain. Hasil penelitian, pengembangan nilai-nilai moderasi beragama yang masih mentah dapat dikembangkan menjadi 32 nilai yang lebih aplikatif untuk memudahkan pemahaman peserta didik mengenai moderasi beragama. Materi yang berisi nilai-nilai tersebut dimasukkan dalam software Videoscript sehingga lebih menarik minat peserta didik untuk belajar. Tahapan pembangunan nilai-nilai karakter yakni pengetahuan, pemahaman, penyadaran, aktivitas dan implementasi sikap. Hasil pendidikan moderasi beragama menunjukkan hasil post test yang signifikan. Hasil penelitian ini dapat diimplikasikan pada pengembangan pembelajaran pendidikan moderasi beragama yang lebih konkrit sehingga mempermudah pemahaman peserta didik.
\end{abstract}

Kata Kunci: moderasi, pengembangan kognitif, karakter, videoscript

\begin{abstract}
Instilling the value of religious moderation needs to be internalized in the field of education. However, the implementation of religious moderation education is still in the form of introducing raw values so that the raw values need to be developed so that the application of values is more applicable. The aim is to find out the factual conditions of the implementation of religious moderation education so that a model of religious moderation education can be developed by developing more applicable values. The method used in this research is research and development, namely by developing the values of religious moderation. The study was conducted at MIN 1 Kendal, with 40 respondents. The analysis is conducted by interactive analysis and $N$-Gain. The results of the research show that the development of raw values about religious moderation can be developed into 32 more applicable values to facilitate students' understanding of religious moderation. The material containing these values is entered into the Videoscript software so that it is more interesting for students to learn. The stages of developing character values in religious moderation education are knowledge, understanding, awareness, activity and attitude implementation. The results of religious moderation education show significant post test results. The results of this study can be implied in the development of more concrete religious moderation education learning so as to facilitate the understanding of students in mastering new values.
\end{abstract}

Keywords: moderation, cognitive development, character, videoscript 


\section{PENDAHULUAN}

Moderasi beragama merupakan salah satu program Kementerian Agama yang sudah tertuang dalam Perpres No. 18 Tahun 2020 tentang RPJMN 20202024. Perpres tersebut ditindaklanjuti dengan penerbitan Peraturan Menteri Agama No. 18 Tahun 2020 tentang Renstra Kementerian Agama 2020-2024 yang telah merencanakan implementasi moderasi beragama dan target penguatan moderasi beragama yang dilakukan secara berkesinambungan. Sosialisasi moderasi beragama tidak hanya diberikan pada tokoh agama dan Aparatur Sipil Negara selaku agen moderasi beragama, tetapi juga diimplementasikan pada bidang pendidikan. Menindaklanjuti program moderasi beragama tersebut, Badan Litbang dan Diklat Kementerian Agama tahun 2019 menerbitkan buku moderasi beragama yang digunakan untuk sekolah dan madrasah. Buku moderasi beragama berisi mengenai konseptual moderasi beragama, pengalaman empirik moderasi beragama; serta strategi penguatan dan implementasi moderasi beragama. Pada bagian konseptual moderasi beragama disebutkan ada 4 (empat) indikator moderasi beragama, yaitu: 1) komitmen kebangsaan; 2) toleransi; 3) antikekerasan; dan 4) akomodatif terhadap kebudayaan lokal (Kementerian Agama, 2019). Pada buku moderasi beragama disebutkan terdapat 9 (Sembilan) nilai moderasi atau wasathiyah, yaitu: tengahtengah (tawassuth), tegak-lurus (i'tidal), toleransi (tasamuh), musyawarah (syura), reformasi (ishlah), kepeloporan (qudwah), kewargaan/cinta tanah air (muwathanah), anti kekerasan (al-la 'unf), dan ramah budaya (i'tibar al-'urf) (Kementerian Agama, 2020). Menurut penelitian yang dilakukan oleh Kawagung (2019) moderasi beragama merupakan nilai fundamental dalam kehidupan social. Sehubungan dengan pentingnya nilai moderasi beragama, maka nilai tersebut dapat diterjemahkan sesuai dengan kondisi lingkungan (Walker et al, 2015).
Nilai-nilai pada moderasi beragama yang akan dikembangkan di sekolah pada dasarnya telah terdapat pada pendidikan karakter yang telah diimplementasikan terlebih dahulu pada sekolah dan madrasah. Sebagaimana diketahui, Kementerian Pendidikan Nasional, Badan Penelitian dan Pengembangan Pendidikan Budaya dan Karakter Bangsa Kementerian Pendidikan Nasional telah mengidentifikasi 18 (delapan belas) nilai yang bersumber dari agama, Pancasila, budaya dan tujuan pendidikan nasional yakni religious, jujur, toleran, disiplin, kerja keras, kreatif, mandiri, demokratis, rasa ingin tahu, semangat kebangsaan, cinta tanah air, menghargai prestasi, bersahabat/komunikatif, cinta damai, gemar membaca, peduli lingkungan, peduli sosial dan tanggung jawab (Agustina \& Arifin, 2020). Dengan demikian, pendidikan moderasi beragama hanya menambah beban pelajaran bagi peserta didik.

Implementasi pendidikan moderasi beragama yang sudah berjalan di Madrasah Ibtidaiyah pada Kabupaten Kendal telah dilakukan dengan pengenalan nilai-nilai moderasi beragama pada pelajaran PAI. Pembelajaran hanya dilakukan dengan metode ceramah yang berisi nilai-nilai moderasi beragama dan contohnya. Pada observasi awal yang dilakukan penulis pada MIN 1 Kendal diperoleh hasil bahwa nilai moderasi beragama dikenal sebagai teori, namun belum dilakukan pada tindakan nyata atau perbuatan. Pengenalan moderasi beragama tersebut hanya berupa nilai mentah sehingga sulit diimplementasikan karena masih abstrak. Hasil penelitian awal tersebut sejalan dengan teori yang dikemukakan oleh Chang (2003) bahwa ada 3 (tiga) penyebab kegagalan pada sosialisasi nilai moral kepada peserta didik yakni 1) penanaman nilai moral berupa teori mentah; 2) sekolah/madrasah belum bekerjasama dengan keluarga peserta didik, lembaga pemerintah, non pemerintah dan seluruh masyarakat; 3 ) kesenjangan pandangan hidup antara pihak yang melecehkan nilai moral dan 
yang menjunjung tinggi nilai moral. Berdasarkan pada fenomena gab yang terjadi, maka perlu dilakukan penelitian.

Pada implementasi moderasi beragama yang telah dilakukan pada penelitian terdahulu terdapat beberapa metode implementasi. Hasil penelitian Samsul (2020) implementasi moderasi beragama dilakukan dengan metode diskusi, kerja kelompok, karya wisata. Pada penelitian Rofik (2021) implementasi moderasi beragama dilakukan dengan pembinaan guru PAI untuk memberikan materi pada kegiatan ekstrakurikuler, sedangkan pada penelitian Mujizatullah (2020) implementasi moderasi beragama dilakukan dengan metode ceramah dan mengintegrasikan nilai moderasi beragama pada mata pelajaran dan ekstrakurikuler. Berdasarkan pada penelitian terdahulu, implementasi moderasi beragama dilakukan baik dalam kegiatan intra maupun ekstrakurikuler dengan metode diskusi, karya wisata, ceramah dan kerja kelompok. Masingmasing metode tersebut dilakukan dengan mengenalkan nilai-nilai moderasi beragama sesuai dengan kebutuhan masing-masing madrasah tanpa melalui rangkaian kegiatan dengan menganalisa domain kognitif, afektif dan psikomotor secara lebih detail. Disisi lain pada penelitian yang dilakukan oleh Chrisantina (2019) untuk pembelajaran nilai-nilai karakter baik pada suatu pendidikan harus menggunakan kurikulum yang berlaku secara universal sehingga akan diperoleh hasil-hasil penguatan nilai yang sama antara satu madrasah dengan madrasah lain. Berdasarkan research gap tersebut, maka pada implementasi pendidikan moderasi beragama perlu dilakukan analisa lebih lanjut sehingga tujuan untuk mewujudkan masyarakat moderat dapat tercapai secara nasional.

Pengembangan mengenai perilaku baik sebagaimana terdapat pada moderasi beragama membutuhkan tahapan yang harus dilalui oleh peserta didik. Hal ini sebagaimana diungkapkan oleh Bloom bahwa tujuan instruksional dalam pembelajaran dapat dikelompokkan menjadi 3 (tiga) domain yakni kognitif, afektif dan psikomotor, yang dapat diterapkan dalam pemberian mata pelajaran (Magdalena et al, 2020). Teori tersebut dikembangkan dalam penelitian Chrisantina (2019) bahwa dalam pembelajaran karakter baik dapat dikelompokkan menjadi 5 (lima) tahapan yakni pengetahuan, pemahaman, penyadaran, aktivitas dan implementasi sikap. Adanya model yang dikembangkan dalam pendidikan nilai-nilai yang berupa karakter baik tersebut perlu dilakukan uji coba untuk menilai efektifitas model tersebut pada implementasi pendidikan moderasi beragama yang terdapat pada Madrasah Ibtidaiyah di Kabupaten Kendal.

Sebagaimana hasil penelitian yang dilakukan oleh Chrisantina (2018) pembelajaran nilai-nilai karakter baik dapat dilakukan dengan bantuan media sesuai dengan kondisi dan tugas perkembangan peserta didik dengan tujuan untuk meningkatkan minat peserta didik dalam mempelajari nilainilai baru. Sehubungan dengan hal tersebut, pada konteks pengenalan nilainilai moderasi beragama juga dilakukan dengan menggunakan multimedia sehingga dapat menarik minat peserta didik dalam mempelajari nilai baru supaya lebih dapat diserap dengan baik. Penggunaan multimedia tersebut didukung oleh penelitian Omodara dan Adu (2014); Malik dan Agarwal (2012) dikatakan bahwa media pembelajaran dan teknologi multimedia merupakan salah satu teknologi yang sangat efektif digunakan sebagai media pembelajaran. Oleh karenanya seiring dengan perkembangan teknologi, maka pendidik juga harus menguasai teknologi dalam media pembelajaran tersebut. Berdasarkan pada uraian mengenai phenomena gap dan research gap yang telah dilakukan oleh peneliti terdahulu, maka perlu dilakukan penelitian mengenai efektifitas model pembelajaran moderasi beragama dengan berbasis multimedia pada peserta didik Madrasah Ibtidaiyah di Kabupaten Kendal. 
Berdasarkan uraian tersebut, maka rumusan masalah dalam penelitian ini adalah 1) Bagaimana kondisi faktual implementasi pendidikan moderasi beragama pada Madrasah Ibtidaiyah di Kabupaten Kendal? 2) Bagaimana efektifitas model implementasi moderasi beragama yang sesuai dengan kebutuhan peserta didik pada Madrasah Ibtidaiyah di Kabupaten Kendal?

\section{KAJIAN PUSTAKA}

Moderasi beragama dipahami sebagai suatu sikap beragama dengan mengutamakan keseimbangan antara pengalaman agama yang dianut dengan penghormatan pengamalan agama yang dianut oleh orang lain, sehingga dapat meminimalisir sikap ekstrem dan fanatic (Sutrisno, 2019). Nilai-nilai moderasi beragama tidak hanya ditujukan pada agen moderasi beragama tetapi juga peserta didik dengan cara memberikan internalisasi nilai moderasi beragama melalui pembelajaran. Sebagaimana telah diuraikan sebelumnya, terdapat 9 (sembilan) nilai moderasi beragama yang ditanamkan pada peserta didik. Kesembilan nilai tersebut harus diperkenalkan secara universal pada seluruh peserta didik sehingga output yang diharapkan dalam hal penguasaan moderasi beragama dapat diperoleh secara merata. Sehubungan dengan adanya nilai-nilai moderasi agama yang merupakan cerminan nilai baik maka pembelajaran yang dilakukan harus memenuhi 3 (tiga) karakter baik yakni sebagai berikut.

1. Pengetahuan moral, yang meliputi 6 (enam) aspek yakni kesadaran moral, mengetahui nilai moral, penentuan perspektif, pemikiran moral, pengambilan keputusan, dan pengetahuan pribadi.

2. Perasaan moral, yang meliputi 6 (enam) aspek yakni hati nurani, harga diri, empati, mencintai hal yang baik, kendali diri, kerendahan hati.

3. Tindakan moral, yang meliputi 3 (tiga) aspek yakni kompetensi, keinginan dan kebiasaan (Lickona, 2015)

Adanya teori pendidikan nilai-nilai karakter sebagaimana diungkapkan oleh Lickona (2015) sejalan dengan taksonomi Bloom bahwa dalam pembelajaran harus meliputi pengembangan dalam hal kognitif, afektif dan psikomotor (Suyadi, 2018). Sehubungan dengan adanya peran kognitif yang sangat mendasar dalam penguasaan suatu pengetahuan dan implementasinya, maka Taksonomi Bloom tersebut ditindaklanjuti dengan penjabaran 6 (enam) dimensi proses kognitif yang harus dikuasai oleh peserta didik, yang meliputi remember, understand, apply, analyze, evaluate dan create (Anderson LW, Krathwohl DR, Airasian PW, 2001). Adanya serangkaian teori tersebut ditindaklanjuti dengan penelitian yang dilakukan oleh Chrisantina (2019) bahwa untuk pembelajaran nilai-nilai karakter baik pada diri seseorang melalui penanaman sebuah karakter baik dan dapat diimplementasikan dalam kehidupan harus meliputi beberapa tahapan yakni pengetahuan, pemahaman, penyadaran, aktivitas, dan implementasi sikap. Tahapan penanaman perilaku baik tersebut telah diujikan pada pembangunan Pendidikan Hak Asasi Manusia yang dilakukan pada peserta didik Sekolah Dasar dengan hasil yang layak dan signifikan.

Pembelajaran pada peserta didik tidak hanya membutuhkan metode yang tepat tetapi juga membutuhkan media yang sesuai dengan kebutuhan, perkembangan teknologi dan informasi sehingga dapat menarik minat peserta didik dalam hal mempelajari hal yang baru dan mampu mengimplementasikan dalam kehidupan bermasyarakat. Pada konteks penelitian ini, penulis menggunakan multimedia sebab multimedia merupakan media pembelajaran yang fleksibel karena dapat digunakan pada berbagai bidang, dan dinilai sebagai media yang bervariasi sesuai dengan kebutuhan (Bimantoro, 2011). Multimedia digunakan dalam penelitian ini karena beberapa alasan 
yakni multimedia dapat mengkonstruksikan pengetahuan agar mudah dipahami, mengkontruksikan pengetahuan yang dapat diimplementasikan, membentuk peserta didik menjadi ahli dan mandiri (Andresen, B. B \& Brink, 2013). Multimedia berupa kartun juga dapat digunakan sebagai media pembelajaran pendidikan karakter dengan tujuan untuk lebih mudah memvisualisasikan nilainilai karakter yang diharapkan (Astuti et al, 2019). Pada konteks penelitian ini, penulis menggunakan videoscript dengan tujuan agar pendidik dapat melakukan modifikasi dan membuat video-video yang sesuai dengan kebutuhan dengan mudah. Penggunaan multimedia sejalan dengan tugas perkembangan anak. Menurut Piaget (dalam Desmita, 2009) anak usia sekolah dasar mempunyai cara berpikir operasional konkrit yakni aktivitas mental ditujukan pada pemikiran nyata, sehingga pengembangan anak meliputi 3 (tiga) proses yakni negasi ditandai dengan anak hanya mampu membedakan antara permulaan dan akhir, hubungan timbal balik ditandai dengan anak mengetahui hubungan sebab akibat dan identitas ditandai dengan anak mampu mengenali satu per satu benda yang ada.

\section{METODE PENELITIAN}

Penelitian ini termasuk dalam kategori metode Research and Development ( $R \& D)$. Penelitian Research and Development ditujukan untuk melakukan penelitian dan pengembangan dengan tujuan menghasilkan produk baru atau menyempurnakan yang telah ada (Sukmadinata, 2006). Penelitian R\&D mempunyai beberapa tahapan yakni melakukan penelitian awal, mengembangkan produk, melakukan uji lapangan dan melakukan revisi untuk perbaikan produk (Gall, M. D., Borg, W. R., $\&$ Gall, 2007). Prosedur yang harus dilalui dalam penelitian ini meliputi tahap pendahuluan, pengembangan dan evaluasi. Pada penelitian ini lokasi penelitian dilakukan pada MIN 1 Kendal. Penelitian dilakukan dengan uji coba pada peserta didik kelas VI dengan harapan peserta didik lebih mempunyai pemahaman yang baik dalam hal pengenalan nilai-nilai moderasi beragama. Populasi peserta didik kelas VI berjumlah 80 peserta didik, dan diambil sampel secara pusposive sampling dengan jumlah 40 peserta didik. Sumber data yang digunakan dalam penelitian ini adalah sumber data primer (wawancara dan observasi serta kuesioner), dan sekunder (jurnal, dokumen pembelajaran pendidikan karakter dan buku yang berhubungan dengan moderasi beragama). Uji keabsahan data dilakukan dengan triangulasi untuk data kualitatif. Adapun analisis data dilakukan dengan model analisis interaktif untuk data kualitatif dan N-Gain pada data kuantitatif.

\section{HASIL PENELITIAN DAN PEMBAHASAN}

\section{Hasil Penelitian}

Pada penelitian ini penulis melakukan wawancara dengan pendidik mengenai pentingnya penanaman nilai moderasi beragama pada peserta didik karena peserta didik adalah generasi penerus yang diharapkan mempunyai pandangan yang moderat pada setiap keanekaragaman yang muncul dalam masyarakat. Tetapi disisi lain, pendidik memberikan keterangan bahwa implementasi pendidikan moderasi beragama harus dilakukan lebih baik daripada implementasi pendidikan karakter sehingga hasil yang diperoleh akan lebih terlihat dalam perilaku baik yang ditunjukkan peserta didik. Pada konteks implementasi pendidikan moderasi beragama pada MIN 1 Kendal diperoleh beberapa evaluasi yakni sebagai berikut.

1. Pendidik mengajarkan nilai-nilai yang masih mentah, jadi penjelasan hanya menerangkan nilai tersebut disertai contoh. Nilai-nilai belum dijabarkan secara detail untuk mempermudah penjelasan pada peserta didik. 
2. Pendidik belum mempunyai metode yang tepat, yang dilakukan pendidik adalah dengan menggunakan metode ceramah.

3. Peserta didik hanya mengetahui moderasi beragama dengan satu nilai yakni menghormati pemeluk agama lain, dengan contoh membiarkan orang menjalankan ibadah. Namun dalam perilaku sehari-hari yang diamati oleh penulis, peserta didik belum dapat mengimplementasikan nilai itu dalam kehidupan dimasyarakat.

4. Terdapat kekuatiran dari pendidik bahwa hasil implementasi pendidikan moderasi beragama akan sama dengan hasil pendidikan karakter yakni pembelajaran nilainilai karakter baik masih sebatas teori tetapi belum dapat diwujudkan dalam implementasi sehari-hari, dan dibuktikan dengan karakter peserta didik yang tidak sesuai dengan nilai moral yang sudah diajarkan.

Sehubungan dengan hal tersebut, penulis mengembangkan 9 (sembilan) nilai moderasi beragama menjadi nilainilai yang lebih aplikatif sehingga dapat dipelajari dengan mudah oleh peserta didik. Adapun pengembangan nilai-nilai mdoerasi beragama dalah sebagai berikut.

Tabel 1. Pengembangan Nilai Moderasi Beragama

\begin{tabular}{|c|c|c|}
\hline No & $\begin{array}{c}\text { Nilai } \\
\text { Moderasi } \\
\text { Beragama } \\
\end{array}$ & $\begin{array}{c}\text { Pengembangan } \\
\text { Nilai Moderasi } \\
\text { Beragama }\end{array}$ \\
\hline 1 & $\begin{array}{l}\text { Tengah- } \\
\text { tengah } \\
\text { (tawassuth) }\end{array}$ & $\begin{array}{ll}\text { - } & \text { Mengutamakan } \\
\text { sifat penengah } \\
\text { - } & \text { Mengutamakan } \\
& \text { keseimbangan }\end{array}$ \\
\hline 2 & $\begin{array}{l}\text { Tegak-lurus } \\
\text { (I'tidal) }\end{array}$ & $\begin{array}{ll}\text { - } & \text { Membela } \\
\text { kebenaran } \\
\text { - }\end{array}$ \\
\hline 3 & $\begin{array}{l}\text { Toleransi } \\
\text { (tasamuh) }\end{array}$ & $\begin{array}{ll}\text { - } & \text { Kedamaian } \\
\text { - } & \text { Menghargai } \\
& \text { perbedaan } \\
\text { - } & \text { Kesadaran } \\
\text { - } & \text { Terbuka } \\
\text { - } & \text { Reseptif }\end{array}$ \\
\hline
\end{tabular}

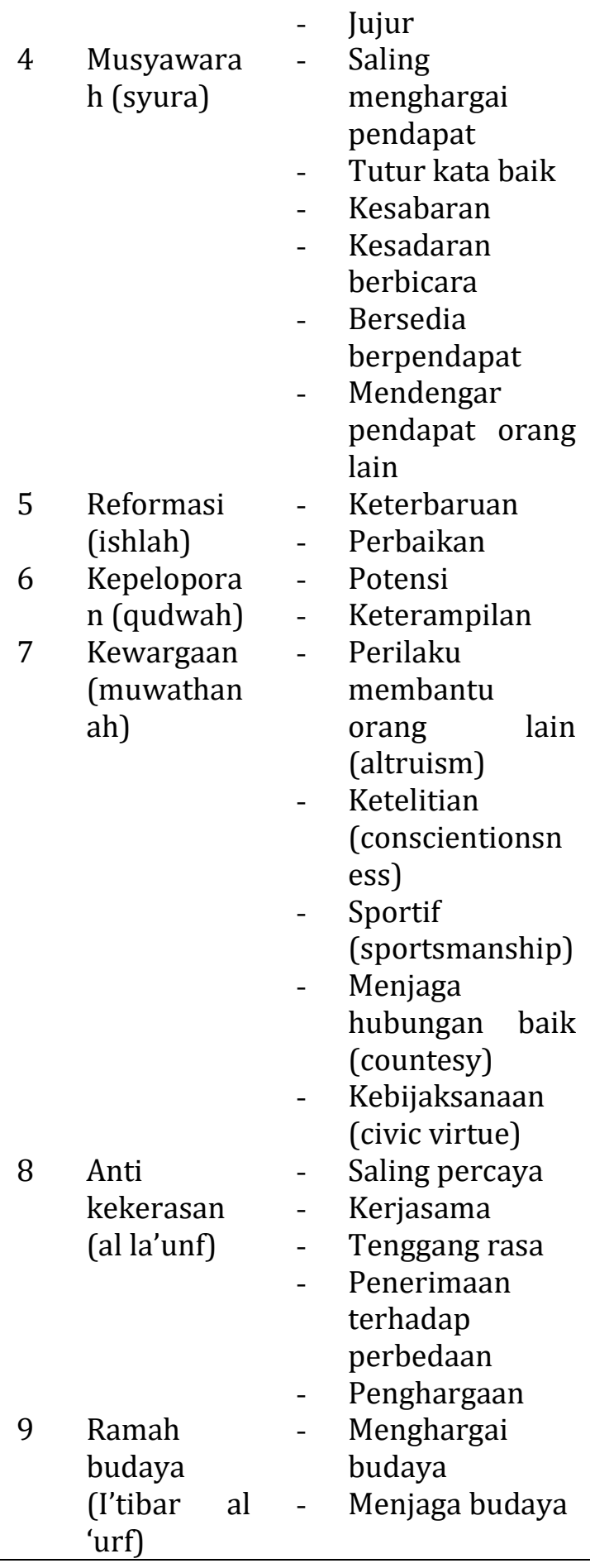

Pada konteks penelitian ini, pengembangan nilai-nilai moderasi beragama dimasukkan dalam materi pendidikan moderasi beragama dengan menggunakan Videoscribe Versi 23.0. Materi tersebut diintegrasikan pada setiap pelajaran yang dapat dikaitkan dengan pendidikan moderasi beragama karena penanaman nilai-nilai baik tidak 
hanya dapat dilakukan dengan sekali pertemuan. Nilai-nilai pengembangan moderasi beragama tersebut telah dilakukan FGD dengan praktisi pendidikan yakni pendidik pada MIN 1 Kendal dan dilakukan uji coba awal pada peserta didik MIN 1 Kendal.

Pada penelitian ini tidak hanya membahas mengenai pengembangan nilai-nilai moderasi beragama tetapi juga tahapan yang harus dilaksanakan sebagaimana dalam hasil penelitian yang telah dilakukan oleh Chrisantina (2019) bahwa dalam pembangunan karakter diperlukan tahapan yang disesuaikan dengan perkembangan kognitif seseorang yakni pengetahuan, pemahaman, penyadaran, aktivitas dan implementasi sikap. Adapun blue print evaluasi efektifitas pada setiap tahapan pembelajaran adalah sebagai berikut.

Tabel 2. Blue Print Efektifitas Pembelajaran

\begin{tabular}{|c|c|}
\hline $\begin{array}{c}\text { Aspek } \\
\text { Penilaian }\end{array}$ & Pernyataan \\
\hline Pengetahuan & $\begin{array}{ll}\text { - } & \text { Tahu } \\
\text { - } & \text { Aplikasi } \\
\text { - } & \text { Analisis } \\
\text { - } & \text { Sintesis } \\
\text { - } & \text { Evaluasi }\end{array}$ \\
\hline Pemahaman & $\begin{array}{ll}\text { - } & \text { Dapat menerjemahkan } \\
& \text { suatu hal dengan bahasa } \\
& \text { sendiri } \\
\text { - } & \text { Pemahaman ide } \\
\text { - } & \text { Membuat kesimpulan } \\
\text { - } & \text { Mampu menilai sebab } \\
& \text { akibat } \\
\text { - } & \text { Mampu menilai efek }\end{array}$ \\
\hline Penyadaran & $\begin{array}{ll}\text { - } & \text { Awareness } \\
\text { - } & \text { Interest } \\
\text { - } & \text { Evaluation } \\
\text { - } & \text { Trial } \\
\text { - } & \text { Adaptation }\end{array}$ \\
\hline Aktivitas & $\begin{array}{ll}\text { - } & \text { Visual, oral and listening } \\
& \text { activities } \\
\text { - } & \text { Writing activities } \\
\text { - } & \text { Motor activities } \\
\text { - } & \text { Mental activities } \\
\text { - } & \text { Emotional activities }\end{array}$ \\
\hline $\begin{array}{l}\text { Implementasi } \\
\text { Sikap }\end{array}$ & $\begin{array}{l}\text { - Mampu memahami } \\
\text { perilaku manusia }\end{array}$ \\
\hline
\end{tabular}

- Mampu memahami sikap

- Mampu memahami latar belakang berlakunya sikap

- Mampu memberikan respon

- Mampu mengambil keputusan

Pada penelitian ini, untuk mengetahui efektifitas model yang digunakan dalam penelitian, maka penulis membagi responden menjadi 2 (dua) kelompok yakni kelompok eksperimen dan kelompok kontrol. Adanya kegagalan dalam penerapan pendidikan karakter yang ditandai dengan masih banyaknya peserta didik yang kurang berkarakter baik, maka pada implementasi pendidikan moderasi beragama perlu dilakukan perbaikan dengan memenuhi tahapan pembelajaran nilai-nilai karakter sebagaimana yang dilakukan oleh Chrisantina (2019) yakni pengetahuan, pemahaman, penyadaran, aktivitas dan implementasi sikap. Adapun pentingnya dan peran setiap tahapan adalah sebagai berikut.

1. Nilai N-Gain untuk tahap pengetahuan adalah 0,61. Tahap pengetahuan mempunyai indikator factual, conceptional, procedur dan metacognitive. Hal tersebut sejalan dengan pernyataan dalam Buku Moderasi Beragama bahwa moderasi beragama adalah suatu pengetahuan untuk mengarahkan cara pandang manusia menjadi lebih moderat dengan mengambil jalan tengah (Kementerian Agama, 2020) 


\section{Descriptives}

\begin{tabular}{|c|c|c|c|}
\hline & KELAS & Statistic & Std. Error \\
\hline & 1 Mean & -2.4250 & 4.27899 \\
\hline $\begin{array}{l}\text { NGAI } \\
\text { N_PE } \\
\text { RSEN }\end{array}$ & $\begin{array}{l}95 \% \text { Lower Bound } \\
\text { Confid } \\
\text { ence } \\
\text { Interv } \\
\text { al for } \\
\text { Mean }\end{array}$ & -11.3810 & \\
\hline & Upper Bound & 6.5310 & \\
\hline & 5\% Trimmed Mean & -1.2109 & \\
\hline & Median & 3.1250 & \\
\hline & Variance & 366.195 & \\
\hline & Std. Deviation & $1.91362 \mathrm{E}$ & \\
\hline & Minimum & -45.45 & \\
\hline & Maximum & 18.75 & \\
\hline & Range & 64.20 & \\
\hline & Interquartile Range & 25.14 & \\
\hline & Skewness & -1.239 & .512 \\
\hline & Kurtosis & .820 & .992 \\
\hline & 2 Mean & 61.8044 & 5.22411 \\
\hline & $\begin{array}{l}\text { 95\% Lower Bound } \\
\text { Confid Upper Bound } \\
\text { ence } \\
\text { Interv } \\
\text { al for } \\
\text { Mean }\end{array}$ & 50.8702 & \\
\hline & 5\% Trimmed Mean & 62.0195 & \\
\hline & Median & 63.3333 & \\
\hline & Variance & 545.826 & \\
\hline & Std. Deviation & $2.33629 \mathrm{E}$ & \\
\hline & Minimum & 25.00 & \\
\hline & Maximum & 94.74 & \\
\hline & Range & 69.74 & \\
\hline & Interquartile Range & 43.82 & \\
\hline & Skewness & -.102 & .512 \\
\hline & Kurtosis & -1.367 & .992 \\
\hline
\end{tabular}

2. Nilai N-Gain pada tahap pemahaman adalah 0,69. Pemahaman perlu dilakukan karena pada tahapan pembangunan kognitif peserta didik usia sekolah dasar merupakan tahapan operasional konkrit, peserta didik akan melihat sebab akibat dan tindakan nyata akan suatu nilai
(Piaget dalam Desmita, 2009) Dengan demikian, pemahaman dilakukan agar peserta didik lebih memahami nilai-nilai yang ditanamkan.

Descriptives

\begin{tabular}{|c|c|c|c|c|}
\hline \multicolumn{3}{|c|}{ KELAS } & Statistic & Std. Error \\
\hline \multirow{30}{*}{$\begin{array}{l}\text { NGAIN_P } \\
\text { ERSEN }\end{array}$} & 1 Mean & & 4.2844 & 6.61712 \\
\hline & $95 \%$ & Lower & & \\
\hline & Confidence & Bound & -9.5654 & \\
\hline & Interval for & Upper & 181212 & \\
\hline & & Bound & 10.1342 & \\
\hline & $5 \%$ Trimme & Mean & 7.5382 & \\
\hline & Median & & 7.1795 & \\
\hline & Variance & & 875.725 & \\
\hline & Std. Deviatic & & $2.95927 \mathrm{E} 1$ & \\
\hline & Minimum & & -100.00 & \\
\hline & Maximum & & 50.00 & \\
\hline & Range & & 150.00 & \\
\hline & Interquartile & Range & 20.00 & \\
\hline & Skewness & & -2.305 & .512 \\
\hline & Kurtosis & & 8.224 & .992 \\
\hline & 2 Mean & & 69.2844 & 3.73410 \\
\hline & $95 \%$ & Lower & 614680 & \\
\hline & Confidence & Bound & 0 & \\
\hline & Interval for & Upper & 771000 & \\
\hline & Mvedn & Bound & 11.1000 & \\
\hline & $5 \%$ Trimme & Mean & 69.4070 & \\
\hline & Median & & 65.4762 & \\
\hline & Variance & & 278.869 & \\
\hline & Std. Deviati & & $1.66994 \mathrm{E} 1$ & \\
\hline & Minimum & & 36.36 & \\
\hline & Maximum & & 100.00 & \\
\hline & Range & & 63.64 & \\
\hline & Interquartil & Range & 23.53 & \\
\hline & Skewness & & .208 & .512 \\
\hline & Kurtosis & & -.224 & .992 \\
\hline
\end{tabular}

3. Nilai N-Gain pada tahap penyadaran adalah 0,74. Penyadaran harus dilakukan karena sesuai dengan pendapat Eckmann et al. (2009) bahwa seseorang yang telah mengikuti pendidikan nilai-nilai karakter harus berperilaku dengan berpenghormatan pada nilai-nilai tersebut. 
Descriptives

\begin{tabular}{|c|c|c|c|c|}
\hline \multicolumn{3}{|c|}{ KELAS } & Statistic & Std. Error \\
\hline \multirow[t]{24}{*}{$\begin{array}{l}\text { NGAIN } \\
\text { PERSE } \\
\mathrm{N}\end{array}$} & $\begin{array}{l}1 \text { Mean } \\
95 \% \\
\text { Confidence } \\
\text { Interval for } \\
\text { Mean }\end{array}$ & $\begin{array}{l}\text { Lower } \\
\text { Bound }\end{array}$ & $\begin{array}{r}.1730 \\
-7.9040\end{array}$ & 3.85902 \\
\hline & & $\begin{array}{l}\text { Upper } \\
\text { Bound }\end{array}$ & 8.2501 & \\
\hline & $5 \%$ Trimme & d Mean & 1.5270 & \\
\hline & Median & & 3.3333 & \\
\hline & Variance & & 297.841 & \\
\hline & Std. Deviatic & & $1.72581 \mathrm{E}$ & \\
\hline & Minimum & & -45.45 & \\
\hline & Maximum & & 21.43 & \\
\hline & Range & & 66.88 & \\
\hline & Interquartil & Range & 26.75 & \\
\hline & Skewness & & -1.045 & .512 \\
\hline & Kurtosis & & 1.042 & .992 \\
\hline & 2 Mean & & 74.4379 & 3.99755 \\
\hline & $\begin{array}{l}95 \% \\
\text { Confidence } \\
\text { Interval for } \\
\text { Mean }\end{array}$ & $\begin{array}{l}\text { Lower } \\
\text { Bound } \\
\text { Upper } \\
\text { Bound }\end{array}$ & 82.8049 & \\
\hline & $5 \%$ Trimme & d Mean & 74.8384 & \\
\hline & Median & & 73.2143 & \\
\hline & Variance & & 319.608 & \\
\hline & Std. Deviatic & & $1.78776 \mathrm{E}$ & \\
\hline & Minimum & & 41.67 & \\
\hline & Maximum & & 100.00 & \\
\hline & Range & & 58.33 & \\
\hline & Interquartil & Range & 30.00 & \\
\hline & Skewness & & -.159 & .512 \\
\hline & Kurtosis & & -.704 & .992 \\
\hline
\end{tabular}

4. Nilai N-Gain aktivitas adalah 0.75 . Menurut Hamalik (2002) setiap anak mempunyai perkembangan kognitif yang berbeda sesuai dengan kemampuan menginterpretasi dan beradaptasi pada lingkungan.
Descriptives

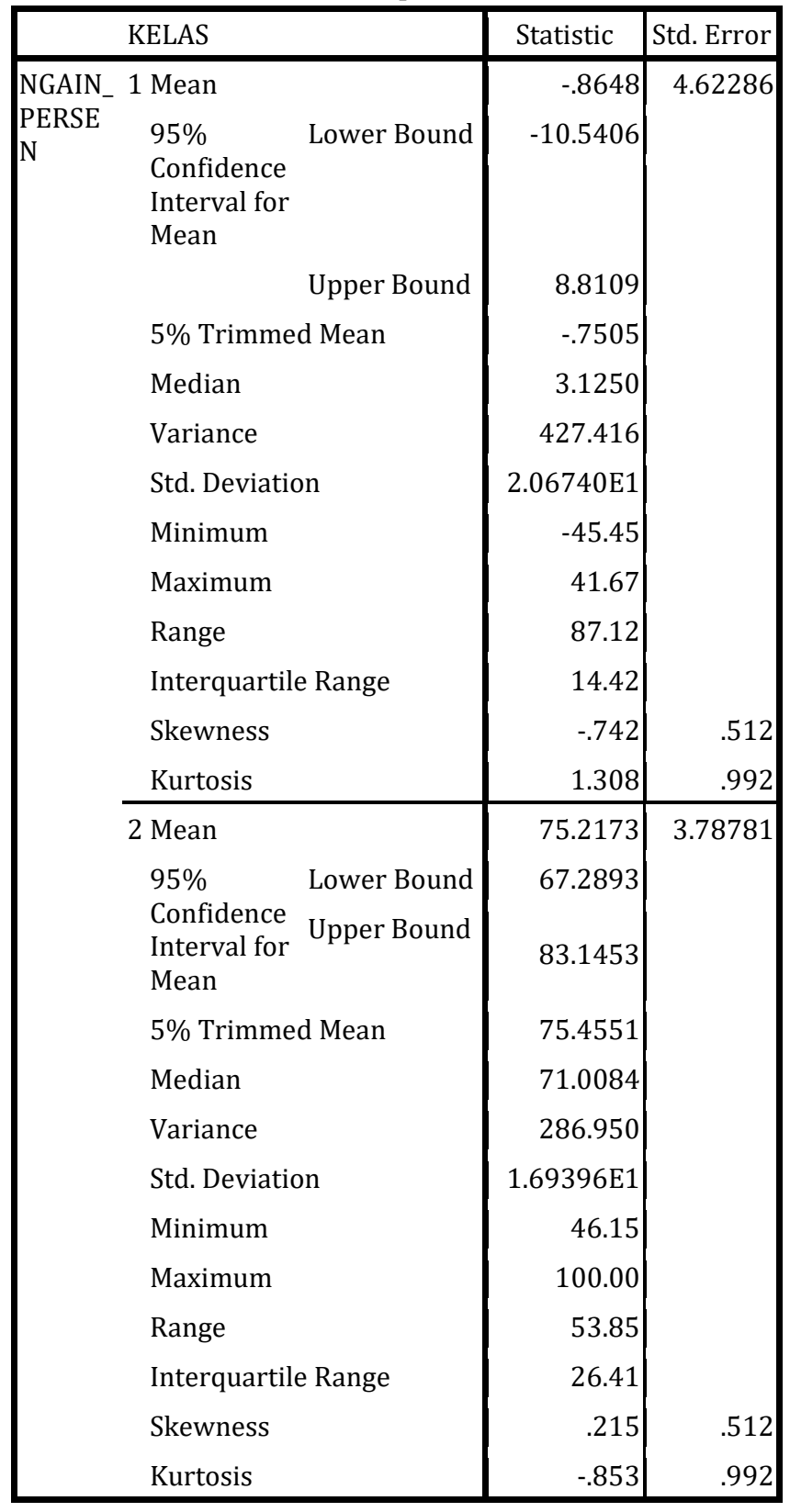

5. Nilai N-Gain pada implementasi sikap adalah 0,82 . Adapun indikator untuk implementasi sikap adalah cognitive response, affective response dan behavioral response. 


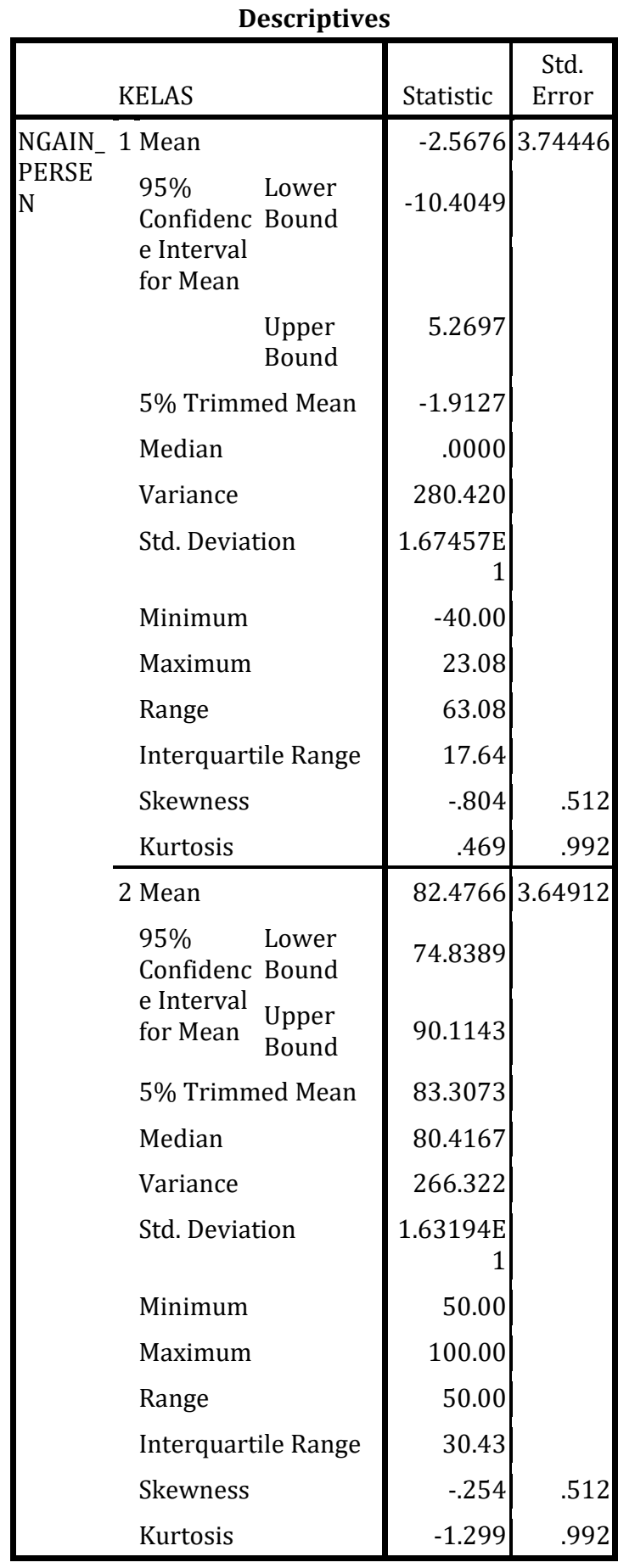

\section{Pembahasan}

Hasil penghitungan dengan menggunakan $\mathrm{N}$ Gain menunjukkan bahwa tahapan dalam setiap pembelajaran nilai-nilai karakter baik pada moderasi beragama dapat dilakukan oleh peserta didik dengan hasil yang signifikan karena pada bagian post test, nilai N Gain mengalami kenaikan yang signifikan. Sebagaimana diketahui bahwa adanya tahapan tersebut dapat meminimalisir terjadinya ketidakjelasan setiap nilai yang diajarkan karena setiap nilai akan diulang artinya dan pemaknaannya mulai tahap pengetahuan hingga tahap implementasi sikap.

Berdasarkan pada hasil penelitian, maka dapat diketahui bahwa pengembangan nilai-nilai moderasi beragama dari nilai mentah menjadi nilainilai yang lebih aplikatif menunjukkan bahwa nilai-nilai tersebut lebih mudah dipahami oleh peserta didik. Hasil pengembangan nilai-nilai moderasi beragama tersebut sejalan dengan Chang (2003) bahwa penanaman berupa nilai mentah sangat rawan dengan kegagalan dalam mensosialisasikan nilai-nilai baik karena nilai yang masih mentah akan lebih bersifat abstrak, jika nilai tersebut dapat diterjemahkan hasil penerjemahan tersebut hanya bersifat terbatas. Tetapi ketika nilai tersebut telah dilakukan breakdown menjadi beberapa indikator, maka nilai-nilai baik akan lebih mudah dipahami dan diaplikasikan dalam kehidupan sehari-hari. Disisi lain, Chang (2003) menjelaskan bahwa penyebab kegagalan lain adalah adanya kesenjangan antara pihak yang melecehkan nilai moral dengan pihak yang memberikan penghargaan pada nilai moral. Pada konteks penelitian ini, pelecehan pada nilai moral terjadi karena kurangnya pemahaman nilai-nilai moral tersebut secara lebih aplikatif. Nilai yang mentah akan sangat abstrak untuk diwujudkan, dengan demikian penjabaran nilai-nilai menjadi lebih aplikatif akan meminimalisir terjadinya pelecehan pada nilai moral. Penanaman nilai-nilai karakter baik harus diikuti dengan penyadaran sehingga penyadaran tersebut akan diikuti dengan implementasi sikap. Dengan demikian tahapan pembelajaran nilai-nilai karakter sebagaimana diungkapkan dalam penelitian Chrisantina (2019) dapat pula dibuktikan pada penelitian ini.

$$
\text { Adanya tahapan dalam }
$$

pembangunan nilai-nilai karakter tersebut, maka pengenalan suatu nilai khususnya pendidikan moderasi beragama pada MIN 1 Kendal tidak hanya 
berbasis ceramah yang hanya mengasah kognitif, tetapi menurut Taksonomi Bloom pengembangan kognitif jika tidak diikuti dengan afektif dan psikomotor hanya akan menjadi teori yang tidak berfungsi karena peserta didik hanya berada pada tahap mengetahui, namun belum diarahkan untuk implementasi.

Pada konteks penelitian yang dilakukan pada MIN 1 Kendal, peserta didik yang telah mengikuti pendidikan moderasi beragama yang dikembangkan dalam penelitian harus ditindaklanjuti dengan upaya komprehensif sekolah pada lingkungan khususnya adalah lingkungan keluarga. Pihak sekolah tidak hanya memberikan ilmu dan nilai moderasi beragama pada lingkungan sekolah tanpa adanya tindak lanjut, karena masa perkembangan anak usia sekolah dasar bukan hanya membutuhkan pemahaman teori sebab akibat sebagaimana diungkapkan oleh Piaget dalam Desmita (2009) tetapi juga membutuhkan keteladanan. Hal ini sebagaimana diungkapkan oleh Hamalik (2002) bahwa dalam masa perkembangan kognitif anak, setiap anak memiliki cara tersendiri dalam menginterpretasikan dan beradaptasi dengan lingkungan. Anak memiliki schemata yang berupa konsep dalam pikiran sebagai hasil pemahaman terhadap objek dalam lingkungannya. Pemahaman tersebut berasal dari proses asimilasi antara objek dengan konsep yang ada dalam pikiran dan akomodasi antara konsep dalam pikiran untuk menafsirkan objek. Dengan demikian, untuk menghasilkan kualitas pemahaman nilai-nilai mdoerasi beragama pada lingkungan sekolah/madrasah perlu dilakukan pendekatan pada keluarga sebagai lingkungan terkecil dimana peserta didik tinggal. Teori tersebut sejalan dengan penelitian yang dilakukan oleh Pala (2011) bahwa penanaman karakter baik atau nilai baik tidak dapat dilakukan pada satu waktu tetapi membutuhkan konsistensi dalam proses pengajaran, pemberian contoh, pembelajaran dan pelatihan.
Pada konteks implementasi pendidikan karakter maupun pendidikan moderasi beragama yang sudah diterapkan di MIN 1 Kendal, terdapat kelemahan pada perencanaan pendidikan yang kurang melakukan analisa baik analisa dalam hal output yang diharapkan. Hal ini sebagaimana hasil penelitian yang dilakukan oleh Agboola dan Tsai (2012) bahwa implementasi pendidikan karakter atau pendidikan nilai-nilai yang baik perlu dilakukan perencanaan dan pembuatan kebijakan yang dapat diaktualisasikan dalam pendidikan moral. Dengan demikian, pada konteks implementasi pendidikan moderasi beragama yang telah dilakukan pada MIN 1 Kendal, implementasi pendidikan moderasi beragama dilakukan tanpa perencanaan yang matang dengan melakukan analisa, sehingga hasil implementasi moderasi beragama yang telah dilakukan tidak signifikan. Hal itu sebagaimana dibuktikan pada hasil wawancara yang dilakukan oleh penulis dengan peserta didik bahwa penguasaan nilai-nilai moderasi beragama hanya sebatas menghormati orang dengan agama berbeda, padahal nilai-nilai moderasi beragama sangat kompleks. Dengan demikian, untuk meminimalisir terjadinya kegagalan dalam implementasi pendidikan moderasi beragama, pembelajaran nilai-nilai karakter baik tersebut perlu dilakukan secara konsisten dan berkesinambungan yakni dengan memperkenalkan nilai-nilai sebagai pengetahuan yakni sebagai dasar pembentukan kognitif seseorang. Setelah pengetahuan tersebut dikuasai, maka perlu dilakukan pemahaman sehingga nilai-nilai moderasi beragama dapat dipahami dengan baik, bukan hanya sebatas pengetahuan. Langkah berikutnya adalah penyadaran yang diwujudkan dengan melakukan flashback pada perilaku-perilaku peserta didik jika disinkronkan dengan nilai-nilai moderat yang dikembangkan dalam penelitian ini, dan dilanjutkan dengan aktivitas sehingga pendidik dapat memberikan penilaian mengenai cara peserta didik 
dalam berperilaku, serta diwujudkan dalam implementasi sikap.

\section{PENUTUP}

Adapun simpulan pada penelitian ini adalah sebagai berikut.

1. Pendidikan moderasi beragama pada MIN 1 Kendal telah diperkenalkan sebagai nilai mentah sehingga kurang aplikatif, dengan demikian hasil atau output yang diharapkan tidak akan maksimal karena kesulitan dalam menerjemahkan suatu nilai yang masih abstrak.

2. Pengembangan nilai moderasi beragama dapat dilakukan hingga 32 nilai konkrit yang dapat diterjemahkan oleh peserta didik usia sekolah dasar dengan mudah sesuai dengan tahapan pembangunan nilai karakter yakni pengetahuan, pemahaman, penyadaran, aktivitas dan implementasi sikap. Hasil pembelajaran Pendidikan moderasi beragama pada MIN 1 Kendal menunjukkan perbedaan yang signifikan sehingga berpengaruh pada perbaikan perilaku.

Saran yang dapat dihasilkan dalam penelitian ini adalah sebagai berikut.

1. Hasil penelitian ini direkomendasikan untuk diterapkan pada pembelajaran pendidikan moderasi beragama di sekolah dasar/madrasah ibtidaiyah karena penelitian ini telah mengembangkan 32 nilai moderasi beragama yang lebih konkrit sehingga lebih mudah diaplikasikan dan diwujudkan dalam kehidupan sehari-hari.

2. Tahapan pembelajaran pada pembangunan nilai-nilai karakter yakni pengetahuan, pemahaman, penyadaran, aktivitas dan implementasi sikap dapat diterapkan pada setiap sosialisasi penguatan moderasi beragama karena pemahaman secara teori tidak akan dapat mewujudkan perilaku yang baik jika tidak diikuti dengan tahapan pembangunan nilai-nilai karakter lain.

\section{DAFTAR PUSTAKA}

Agboola, Alex., Tsai, Kaun Chen. (2012). Bring Character Education into Classroom. European Journal of Educational Research Vol. 1, No. 2, p 2163-170

Agustina, Rahidatul Laila., Arifin, Johan. (2020). Implementasi Pendidikan Karakter Untuk Membentuk Kepribadian Siswa Sekolah Dasar. Elementa: Jurnal PGSD STKIP PGRI Banjarmasin. Vol. 1, No. 3, Februari 2020 Halaman: 198-208

Andresen, B. B \& Brink, K.V.P. (2013). Multimedia in Education: Curriculum. Moscow: UNESCO: IITE

Anderson LW, Krathwohl DR, Airasian PW, et al. (2001). Taxonomy of Learning, Teaching, and Assessing: A Revision of Bloom's Taxonomy of Educational Objectives, 2nd ed, abridged. Boston, MA: Pearson Allyn \& Bacon.

Astuti, Riskiana Widi Astuti., Waluyo, Herman J and Rohmadi, Muhammad. (2019) Character Education Values in Animation Movie of Nussa and Rarra. Budapest International Research and Critics Institute-Journal (BIRCI-Journal) Volume 2, No 4, November2019, P 215-219 
Bimantoro L. (2011). Visualisasi Rasi Bintang Berbasis Multimedia, Fakultas Sains dan Teknologi. Jakarta : Universitas Islam Negeri Syarif Hidayatullah Jakarta yang diakses tanggal 17 November melalui 2021 World WideWeb: http://repository.uinjkt.ac.id/dspace/simplesearch?query=repository.uinjkt.ac.id\%2F... \%2FLU CKY\%2520BIMANTORO-F..\&submit=Go

Chang, W. (2003). Sosialisasi Nilai-nilai Moral dalam Http://www.kcm.com/htmdiambil pada tanggal, 19 November 2021.

Chrisantina, Vita Santa Kusuma. (2018). Rencana Model Pembangunan Pendidikan Hak Asasi Manusia Pada Sekolah Dasar Di Kabupaten Kendal Jawa Tengah, Indonesia. Optima Planner Jurnal Perencanaan, Vol 1 No, 1, hal 14-22, Juni 2018.

Chrisantina, Vita Santa Kusuma. (2019). Model Pelatihan Pendidikan Karakter Berbasis Hak Asasi Manusia Dengan Berbantuan Multimedia pada Pendidik Sekolah Dasar. Disertasi Program Doktoral Manajemen Kependidikan, Universitas Negeri Semarang.

Desmita. (2009). Psikologi Perkembangan. Bandung: PT Remaja Rosdakarya.

Eckmann M, Scherr A, Zimmer H, Fritzshe KP. (2009). History and Human Rights Education: A Challenge for Education. From www.stifung-evz.de/fileadmin/user_pub_mrb_166-191.

Gall, M. D., Borg, W. R., \& Gall, J. P. (2007). Educational research introduction (6th ed.). White Plains, NY: Longman Publishers USA.

Hamalik, Umar. (2002). Perencanaan Pengajaran Berdasarkan Pendekatan Sistem. Jakarta: Bumi

Kawangung, Yudhi. (2019) Religious Moderation Discourse in Plurality of Social Harmony in Indonesia. International Journal of Social Sciences and Humanities. Vol. 3 No. 1, April 2019, p $160 \sim 170$

Lickona, Thomas. (2015). Educating for Character, Mendidik untuk Membentuk Karakter. Jakarta: Bumi Aksara.

Magdalena, Ina., Islami, Nur Fajriyati., Rasid, Eva Alanda dan Diasty, Nadia Tasya. (2020). Tiga Ranah Taksonomi Bloom Dalam Pendidikan. EDISI : Jurnal Edukasi dan Sains Volume 2, Nomor 1, Juni 2020; 132-139

Malik, S and A. Agarwal. (2012). Use of Multimedia as a New Educational Technology Tool A Study. International Journal of Information and Education Technology, Vol. 2, No. 5, October 2012.

Mujizatullah. (2020). Pendidikan Moderasi Beragama Peserta Didik Madrasah Aliyah Muhammadiyah ISIMU Kabupaten Gorontalo. Educandum: Volume 6 Nomor 1 Juni 2020, p 48-61

Omodara, O. D. and E.I.Adu. (2014). Relevance of Educational Media and Multimedia Technology for Effective Service Delivery in Teaching and Learning Processes. IOSR Journal of Research \& Method in Education (IOSR-JRME) e-ISSN: 2320-7388,p-ISSN: 2320-737X Volume 4, Issue 2 Ver. I (Mar-Apr. 2014), PP 48-51 www.iosrjournals.org 
Pala, Aynur. (2011) The Need for Character Education. International Journal of Social Sciences and Humanity Studies. Vol 3, No 2, 2011, p 3-32

Rofik, Nur Muhammad. (2021). Implementasi Program Moderasi Beragama di Kementerian Agama Kabupaten Banyumas pada Lingkungan Sekolah. Program Studi Pendidikan Agama Islam Pascasarjana Institut Agama Islam Negeri Purwokerto.

Samsul, AR. (2020). Peran Guru Agama Dalam Menanamkan Moderasi Beragama. Al-Irfan, Volume 3, Nomor 1, Maret 2020, p 37-51.

Sukmadinata, Nana Syaodih. (2006). Metode Penelitian Pendidikan. Bandung: PT. Remaja Rosda Karya

Sutrisno, E. (2019). Aktualisasi Moderasi Beragama di Lembaga Pendidikan. Jurnal Bimbingan Bimas Islam.Kemenag.go.id, 12 https://jurnalbimasislam. kemenag.go.id/jbi/article/view/113

Suyadi. (2018). Strategi Pembelajaran Pendidikan Karakter. Bandung: PT. Remaja Rosdakarya

Tim Penyusun Kementerian Agama RI. (2020). Moderasi Beragama, Cetakan Keempat. Jakarta: Kementerian Agama RI

Walker, David I., Roberts, Michael P. \& Kristjánsson, Kristján. (2015) Towards A New Era of Character Education in Theory and in Practice. Educational Review, 67:1, 79-96.

Peraturan

Perpres No. 18 Tahun 2020 tentang RPJMN 2020-2024

Peraturan Menteri Agama No. 18 Tahun 2020 tentang Renstra Kementerian Agama 2020-2024 